Journal of Educational

Technology \& Online Learning

Volume 4 | Issue $4 \mid 2021$

http://dergipark.org.tr/jetol

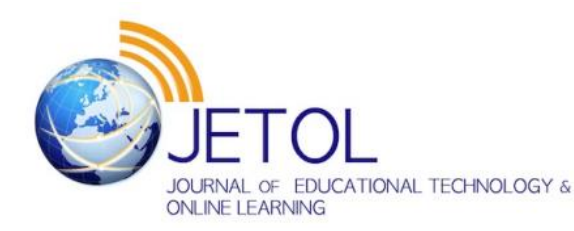

\title{
Distance education in the Covid-19 pandemic period: opinions of primary pre- service teachers about teaching practice course
}

\author{
Ümit IZGI ONBAŞILI ${ }^{\text {* }}$ (D), Burcu SEZGINSOY ŞEKER b (D) \\ ${ }^{a}$ Mersin University, Turkey \\ b Balıkesir University, Turkey
}

Suggested citation: Izgı Onbaş1l, Ü. \& Sezginsoy Şeker, B. (2021). Distance education in the Covid-19 pandemic period: opinions of primary pre-service teachers about teaching practice course. Journal of Educational Technology \& Online Learning, 4(4), 726-744.

\begin{tabular}{|c|c|}
\hline Article Info & Abstract \\
\hline $\begin{array}{l}\text { Keywords: } \\
\text { Covid-19 } \\
\text { Primary Pre-service teacher } \\
\text { Distance education }\end{array}$ & $\begin{array}{l}\text { The Covid-19 pandemic, which has come to the fore all over the world, has had serious } \\
\text { effects in the education process as in every field. Countries have urgently tried to make } \\
\text { the necessary arrangements regarding their education systems. Similarly, in Turkey, the } \\
\text { Ministry of National Education tried to transfer the courses in formal education to the } \\
\text { distance education system in all schools and Higher Education Institutions. However, } \\
\text { until this time, only theoretical courses and courses regarding the technology-based } \\
\text { practices were included in distance education. In this sense, serious difficulties have } \\
\text { experienced especially in practical courses such as laboratories and internships. One of } \\
\text { the biggest debates in education faculties, which had to take a break from face-to-face } \\
\text { education as of March } 2020 \text {, has been about how to conduct internship courses such as } \\
\text { teaching practice in the distance education process. For this reason, this study aimed to } \\
\text { examine the opinions of primary school pre-service teachers about the teaching practice } \\
\text { course during the pandemic process. Both pre-service teachers and primary school } \\
\text { students, whom they taught and observed within the scope of the teaching practice } \\
\text { course, experienced the distance education process for the first time. It is very important } \\
\text { to investigate the positive and negative experiences of the primary school pre-service } \\
\text { teachers who will start to work as the teachers of the future and to take the necessary } \\
\text { precautions. In this context, this study, which was carried out as a phenomological } \\
\text { study, was conducted with } 8 \text { pre-service teachers who were enrolled in a teaching } \\
\text { practice course at a state university in the fall semester of } 2020-2021 \text {. While the data } \\
\text { were obtained from open-ended questions, the reports and lesson plans kept during the } \\
\text { semester were examined by the researchers. The data were analyzed by qualitative } \\
\text { analysis methods. }\end{array}$ \\
\hline
\end{tabular}

\section{Introduction}

The Covid-19 virus, which emerged in China in December 2019, started to pervade Turkey as of March 11, 2020 (Ministry of Health, 2020.) The Covid-19 pandemic in Turkey has affected education, as it has in all areas of daily life. In the face of the coronavirus epidemic, which caused at least $91 \%$ of students around the world to take a break from education, emergency distance education has been put into effect by many countries as a solution tool. To prevent the spread of the epidemic, all education levels from primary schools to universities had to take a break from face-to-face education. This situation prompted countries to take

\footnotetext{
* Corresponding author: Primary Education Department, Mersin University, Turkey.

e-mail address: umitizgi@mersin.edu.tr

This study was partly presented as a proceeding at the 1st International Conference on Educational Technology and Online Learning

Conference held between 22-24 September 2021.
} 
urgent decisions on education, causing the emergency distance education process to start in schools. Educational institutions in Turkey were temporarily closed as of March 25, 2020 (CHE, 2020). After this process, education in schools affiliated to the Ministry of National Education (MoNE) began with the EBA platform and universities began to conduct all courses with distance education. Universities have started to work quickly to continue both theoretical and applied courses and have made the transition to urgent distance education. Since this transition was carried out quite quickly, an evaluation could not be made about the adaptation of students to the requirements of distance education (Iyer, Aziz, \& Ojcius, 2020). For this reason, pre-service teachers attending the last year of education faculties of universities did both the theoretical part of the "Teaching Practice I-II" internship course and the 6-hour weekly practical part online. During the internship, they followed the MoNE EBA channel and completed their internship for 6 hours per week on different online platforms such as Zoom. They were able to meet with the primary school students they observed and lectured through the cameras. To investigate the reflections of this situation from different perspectives, perhaps for the first time in world history, in-depth research was conducted with 8 pre-service teachers attending the "Teaching Practice I" course in the fall term of 2020-2021.

\section{Literature}

As of April 2020, more than 1.5 billion students in 194 countries, representing $91.3 \%$ of total enrolled students, have been affected by the Covid-19 pandemic (UNESCO, 2020). This pandemic has had important pedagogical impacts. In this period, there was a significant increase in demand for distance education and the importance of distance education services in society began to be understood. Distance education, with the support of developing web-based platforms and technologies, offers individuals educational environments independent of time and space (Bilgiç \& Tüzün, 2015). Distance education, in which learning, all kinds of interaction between the learner and the instructor takes place, and brings the learner and the instructor together, differs from formal education in terms of teaching process (Kahraman, 2020). However, it is necessary to clearly understand the key concepts that are important in this rapid transformation due to the pandemic. It is vital to understand the important distinctions between the concepts of emergency distance education and distance education. According to Bozkurt \& Sharma (2020), the differences between these two concepts are explained as follows; emergency distance education is a necessity, distance education is an option; while emergency distance education produces instant solutions, distance education tries to produce more permanent solutions; in crisis situations, emergency distance education continues with the available resources, while more planned and organized activities are carried out in distance education. In times of crisis such as the pandemic, universities had to quickly switch to emergency distance education practices. Although there are distance education centers in many universities in Turkey, this process has been painful. There are also people who do not have previous teaching experience in distance education, especially among the academicians who conduct undergraduate courses in universities. Lots of research projects has been done and continues to be done around the world in 20202021 on emergency distance education caused by the pandemic. In these studies, negative situations and limitations can be detected as well as positive reflections. Russell (1999) in his research; states that distance education will not be any different from face-to-face education if it is planned correctly. Allen, Bourhis, Burrell, and Mabry (2002) state in their research that there is no difference between distance education and traditional education in higher education. In this sense, how the distance education process is structured is also very important.

These rapid developments due to the pandemic have revealed that the distance education system in Turkey should be strengthened in terms of infrastructure, content and pedagogy and that the quality should be increased (Can, 2020). The Covid-19 pandemic has also changed the design and structure of traditional education programs. Teacher educators have begun to need a design that will guide their transition to online teaching and help pre-service teachers gain competencies in the use of learning technologies in their future classrooms (Baran \& AlZoubi, 2020, p. 365). To support pre-service teachers in the teaching practice course, which usually takes place in the senior year of faculty of education, cooperation is arranged with 
internship schools (Nel \& Marais, 2020). However, the programs of education faculties were not really ready for distance education until the Covid 19 pandemic emerged (Hojeij \& Baroudi, 2021).

Due to the Covid-19 pandemic in Turkey, universities that normally provide formal education have made rapid adjustments and switched to emergency distance education. The lectures were synchronous (simultaneous), asynchronous (asynchronous), or hybrid (synchronous-asynchronous) (Durak, Çankaya \& İzmirli, 2020). Since face-to-face education could not be provided due to the pandemic, teacher educators quickly started the distance education process by taking advantage of the available technological opportunities to ensure the continuity of learning and that pre-service teachers could adopt online distance learning. The important point here is that; pre-service teachers had to both attend all courses in their undergraduate programs and meet their primary school students on online platforms. They had to be successful in distance education in many important points such as lecture, classroom management, effective use of time, and motivating the students. Although the teacher of the class in primary schools had the chance to have face-to-face training with their students before, the pre-service teachers did not have such a chance. They were expected to observe the students they saw for the first time in their lives and explain their lesson plans.

This rapid introduction to distance education provided a clearer understanding of many pedagogical and practical problems. The main purpose of teaching practice courses is to contribute to the development of teacher candidates (Mohammad Nasri and et al., 2020). Even though the Covid-19 pandemic has caused serious challenges for many fields, it has also provided opportunities for teacher candidates, such as greater involvement in teaching and learning online (Valdez, Ugalingan \& Edjan, 2021).

When the literature is examined, it is seen that researches were conducted with different study groups regarding distance education and teaching practice during the pandemic period. The difference of this article from other studies is that it is handled within the sample group of primary school teacher candidates. The sample group of our research gains more importance, especially since primary school first grade students will be the direct addressees of the problems they experience in the literacy process. In addition, the primary school teacher candidates in the sample group we discussed could not perform the school experience lesson face-to-face, and they were among the first groups to do an online internship.

The reflections of the suspension of face-to-face education at all levels of education will be understood more clearly in the following years. In the distance education process, the "Teaching Practice" course was held online under the guidance of the practice teacher. In this study, the views of pre-service teachers about their distance education experiences are included within the scope of the teaching practice course. It is very important to determine the opinions of pre-service teachers who will work in an practice-oriented field such as the teaching profession. For this reason, this study aimed to investigate the distance education experiences of the primary school pre-service teachers within the "Teaching Practice I" course. For this purpose, answers to the following problems and sub-problems are sought.

What are the opinions of the primary school pre-service teachers about the "Teaching Practice I" course conducted in distance education during the pandemic process?

1. What are the opinions of pre-service teachers towards practice mentors in the distance education process?

2. What are the views of pre-service teachers towards students in the distance education process?

3. What are the advantages and limitations of internship practices for pre-service teachers in the distance education process?

4. What are the views of pre-service teachers on remote teaching of practice courses?

5. What are the solution suggestions of the pre-service teachers for the problems occured in their distance education experiences? 


\section{Methodology}

\subsection{Research Model/Design}

In this study, which examines the views of pre-service teachers on internship practices in the distance education process, a phenomenological study pattern, which is one of the qualitative research traditions, was used. Phenomenological studies are studies that enable us to focus on phenomena that we are aware of in daily life but do not have an in-depth and detailed understanding (Yıldırım \& Şimşek, 2014). Individual experiences form the basis of phenomenological research. In this approach, the experiences and perceptions of the participants are important and it is based on examining the meanings they attribute to the events.

\subsection{Data Collecting Tools}

Semi-Structured Interview Form: In the research, a semi-structured interview form developed by the researchers was used as a qualitative data collection tool. Preservice teachers were asked to fill in the interview form online. According to Merriam (2018), semi-structured interview forms allow participants to express the world they perceive with their own thoughts. In this study, it was deemed appropriate to use the semi-structured interview form as a data collection tool, since how the study group perceived their experiences was analyzed based on their statements. Interview questions were created after examining similar studies (Türküresin, 2020; Y1ldırım, Y1ldırım, Çelik \&Karaman, 2014) on distance education in the literature. Two field experts were consulted for the content validity of the form. In the interview form, it was requested that the questions be clearly stated. In general, the interview form was found suitable and the interview questions were finalized. In addition, the weekly lesson plans prepared by the pre-service teachers during the internship, the final file of the teaching practice, the observation reports about the courses they attended online contributed to the research. This contribution was made during the researchers' preparation of the research questions. In the observation reports of the pre-service teachers, the sentences about the problems they encountered with the distance education process and the solution suggestions they put forward contributed to the formation of the research questions. Some of the questions asked within the scope of the research are: "What are your views on the practice guidance teachers in your internship course during your distance education process?; What are your views on the students in your internship course during your distance education process?; What are the advantages and limitations of internship applications in the distance education process?; What are your views on remote teaching of practical courses such as Teaching Practice?; What are your suggestions for solutions to the problems experienced in internship practices during the distance education process?"

\subsection{Sampling or Study Group}

While determining the study group of the research, criterion sampling strategy was used (Patton, 2002). Basically, the following criteria were taken into account in the study; the voluntary participation of preservice teachers, they have successfully completed the "School Experience" course and regularly attend the courses with distance education. Participants are students who have successfully completed the "School Experience" course, which is an observational internship course in the 2019-2020 spring term. However, due to the outbreak of the pandemic in March 2019, they had to complete their internships online as of that date. Within the scope of the school experience course, they had the chance to observe the schools only during the weeks they could go face-to-face (up to 4 weeks). For this reason, it is a group that cannot have a real internship experience until the "Teaching Practice I" course in the fall 2021 semester. They are teacher candidates who regularly participate in their online internships during all weeks from the beginning to the end of their internships in this application and do not have absenteeism. The study group of this research consists of senior pre-service teachers of the 2020-2021 academic year in the faculty of education and Department of Primary School Teaching of a state university. The research data were collected by the researchers during the 14-week period of the "Teaching Practice I" course in the fall semester. Eight (7 Female, 1 Male) pre-service teachers who took teaching practice course remotely during the pandemic period were included in the research. 


\subsection{Data Analysis}

Content analysis method was used in the analysis of the data, and direct quotations were made from the statements given by the participants from time to time (Yıldırım \& Şimşek, 2014). Before the analysis, the interview forms were named (P1, P2, P3...) and the answers were gathered under the question headings. According to the research questions. Afterwards, the answers given by the participants were grouped according to their similarities and differences, and the positive and negative answers were separated from each other. The analysis was completed by creating codes from the answers given by the participants.

\subsection{Validity and Reliability}

To increase the validity and reliability of the research, data diversity was made, long-term interaction was ensured, and the data were confirmed. Yıldırım and Şimşek (2014) emphasize the importance of the concept of confirmability in qualitative research and discuss the confirming the results obtained from qualitative research and presenting a logical explanation to the reader. In this study, the codes were read by two researchers separately at different times and created in line with the students' answers given to the questions. The reliability among researchers was calculated according to Miles and Huberman's (1994) formula and was determined as $88 \%$. In terms of a holistic approach in qualitative research, the results are interpreted by considering the natural environment in which the process occurs. In qualitative research, the researcher is involved in the process due to the method of the research. In this research, the researcher participated in Zoom sessions as a participant-observer during the distance education process. Patton (2002) states that validity in qualitative research depends on the researcher's qualifications of being sensitive, talented, skillful, attentive, and analyzing the data. Within the scope of this research, the process was completed in regard of these criteria.

\subsection{Research Procedures}

In Table 1, what was done during the 14 weeks within the scope of the research is explained in detail.

Table 1: Information about the research process

\begin{tabular}{ll}
\hline Week & What's been done \\
\hline 1. & $\begin{array}{l}\text { An online meeting was held with all pre-service teachers. Detailed information was given about the } \\
\text { internship process. }\end{array}$ \\
\hline 2. & $\begin{array}{l}\text { In the rapid transformation experienced due to the pandemic, the opinions of the pre-service teachers } \\
\text { about the effects of the distance education process on primary school students were received in writing. } \\
\text { It was discussed at a meeting held online. }\end{array}$ \\
\hline 3. & $\begin{array}{l}\text { MEB internship schools have been announced. An online meeting was held with pre-service teachers } \\
\text { and practice mentors. }\end{array}$ \\
\hline 4. & $\begin{array}{l}\text { During the distance education process, they observed the practice mentors according to the observation } \\
\text { report given by the researchers and shared them with the researcher at the weekly online meeting. }\end{array}$ \\
\hline 5. & $\begin{array}{l}\text { During the distance education process, they observed the students according to the observation report } \\
\text { given by the researchers and shared them with the researcher at the weekly online meeting. }\end{array}$ \\
They observed the distance education process with its benefits and limitations and all its components \\
and shared it with the researcher at the weekly online meeting.
\end{tabular}




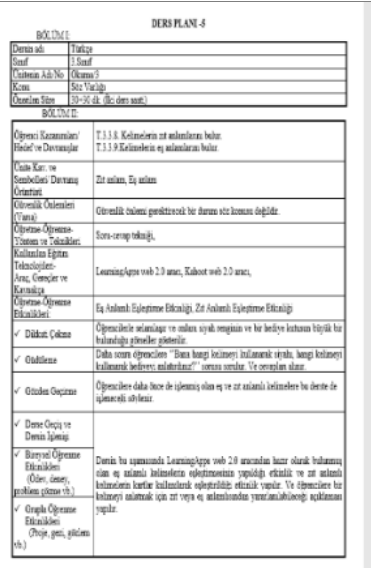

astivn
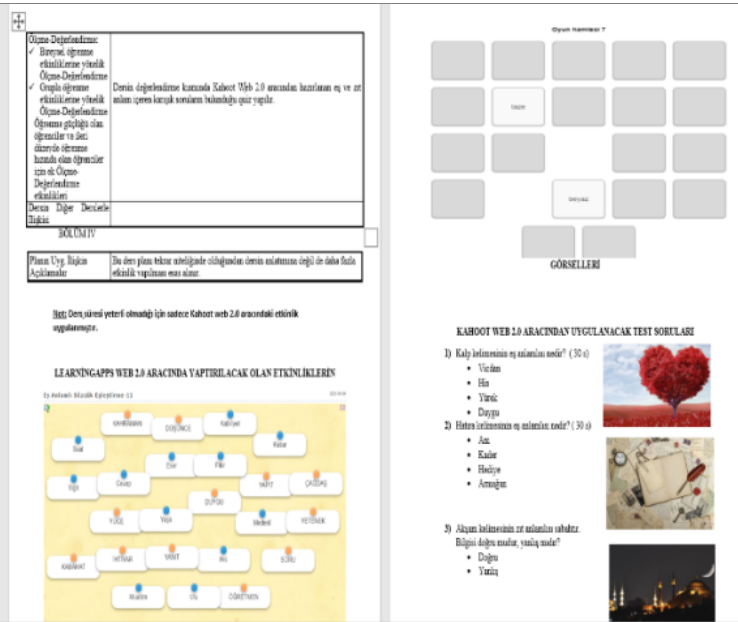

Figure 1. Sample lesson plan prepared by K1 and examples of Web 2.0 supported activities

9. They prepared and implemented a lesson plan supported by Web 2.0 tools that they could use in the distance education system. An example of an activity prepared by K4 is given in Figure 2. BÖLÜM! Web 2.0 Aracı Destekli Etkinlik Kâğıdı

Smıf Düzeyi: 3

Ders Ad1: Fen Bilimleri

Ünite Adl: Bę̧ Duyumuz

Öğrenme Alanı: Canlılar ve Yaşam

Kazanım: F.3.2.1.2. Duyu organlarının temel görevlerini açıklar.

Dersin Hangi Aşamasında Kullanacaksınız? Dersin son aşamasında değerlendirme amaçı̆ kullanacağım.

Hangi Programı Kullandınız? (Web sitesi olarak adresini de paylaşıız). cram.com

https://www.cram.com/flashcards/games/jewel/fen-bilimleri-11817728

Açklama:

Hazırlamı̧̧ olduğum etkinlik oyun tarzındadır. Dersin sonunda öğrenilenlerin pekiştirilmesi için bir tür eşleştirme oyunudur. Verilen sorular ve cevaplar üzerine tiklanarak eşleştirilir. Yanlış

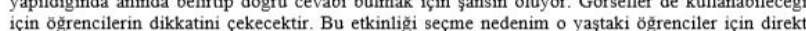

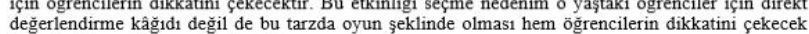
hem de öğrenciler hevesli olacaktır.

Görseller:

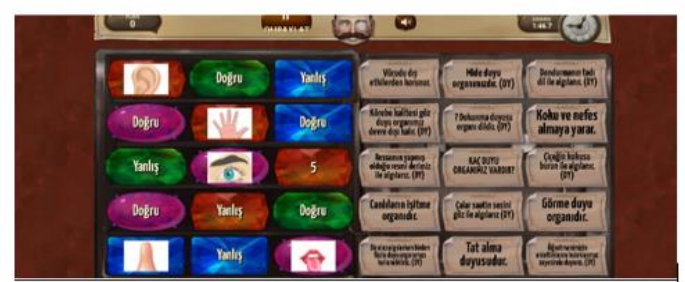

Figure 2. An example of an activity supported by the Web 2.0 tool prepared by K4

10. They prepared and implemented a lesson plan supported by Web 2.0 tools that they could use in the distance education system.

11. They prepared and implemented a lesson plan supported by Web 2.0 tools that they could use in the distance education system.

12. They prepared and implemented a lesson plan supported by Web 2.0 tools that they could use in the distance education system.

13. They prepared and implemented a lesson plan supported by Web 2.0 tools that they could use in the distance education system.

14. They submitted the end-of-term evaluation files.

\subsection{Findings and Discussions}

In this section, the opinions of pre-service teachers about the practice mentors and students in the distance education process were taken. In addition, during the pandemic process, the views of pre-service primary 
school teachers on their distance education experiences within the scope of the teaching practice course were examined in terms of "advantages", "limitations", "positive and negative opinions about teaching the lesson remotely" and "solution suggestions". The codes and themes related to the results obtained are presented in Figure 3.

\section{Opinions of pre-service teachers towards practice mentors in the distance education process}

The opinions of the pre-service teachers towards the practice mentors during the internship process carried out with distance education are presented in the "Figure 3" below.

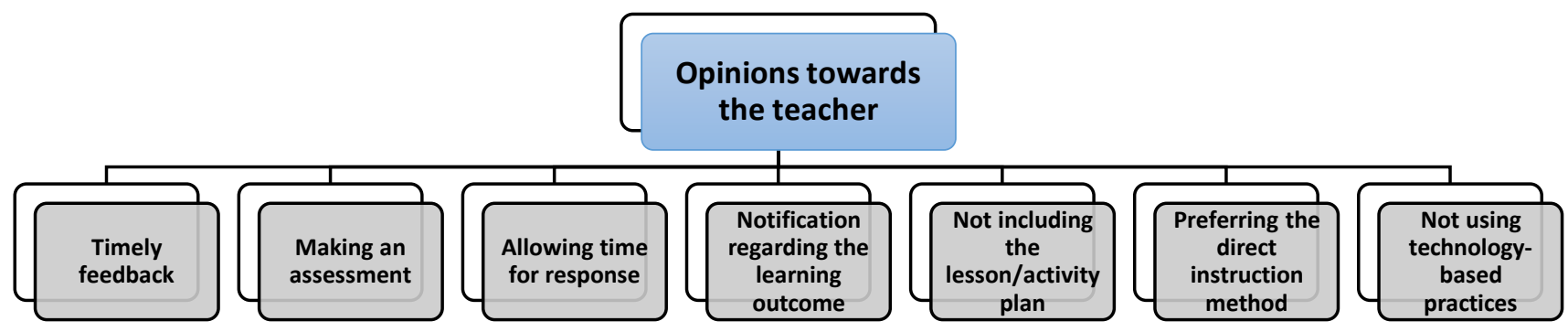

Figure 3. Opinions of pre-service teachers towards practice mentors in the distance education process

When Figure 3, which presents the opinions of pre-service teachers about the mentors, are examined, it is clear that within the scope of positive opinions, the teachers give timely and appropriate feedbacks to the students during the distance education process, they can evaluate the success of the students, they give the students the appropriate time while answering the questions, and they inform the students about the learning outcomes before the lesson starts. It was determined that pre-service teachers handled the most opinions in the category of "timely feedback". Some of the opinions of pre-service teachers suitable for these themes are as follows.

K3. When the student makes a mistake, he/she immediately corrects and gives feedback timely, when he/she asks a question, he/she patiently waits for the students to think and reach the right answer. When they can't give the correct answer, he/she gives clues and helps students reach the correct answer.

K6. Our internship teacher evaluates the performance of the students by having the students solve the questions and exercises related to the subject and by having them read each lesson.

K4. She informed the students in the pre-lesson class about the outcome and explained how it would benefit them when they learned this lesson.

K1. During the activities, he/she gave enough time to the students and let them think about their answers.

In addition to the above-mentioned positive opinions about the practice mentors, the pre-service teachers also mentioned the aspects that need to be improved in teachers. In this context, the pre-service teachers who expressed their opinions stated that the teacher they observed did not include technological-based practices, taught lessons using the direct instruction method, and did not prepare a lesson plan or activity plan. It was determined that pre-service teachers handled the most opinions in the category of "Not including the lesson/activity plan". Some of the opinions of pre-service teachers regarding these themes are given below.

K1. To sum up the teacher's observation in the general sense of the lessons we attended, our teacher did not go through any lesson or activity plan. But he/she used clear, understandable language.

K2. Most of the teachers taught their lessons by using direct instruction and question and answer methods. Different teaching methods and techniques were not included. 
K4. I don't know how our Internship Teacher followed in face-to-face training, which is done only once a week, but he/she had a poor expression in the online course. He/she generally preferred direct insruction method. Despite this, the students did not have difficulty in understanding the subjects.

K5. The only criticism I can make for our Internship Teacher is this; he/she can use technology more actively in the lessons. Apart from that, I think our teacher will be instructive for us.

In addition to the positive characteristics of the pre-service teachers towards the practice mentors, they also stated the features that need to be improved in teachers. In this context, they stated that they're not including technology-based practices, teaching lessons using the direct instruction method, and not preparing a lesson plan or activity plan as limitations. Mentors have an important role in gaining the teaching skills of pre-service teachers in practice courses such as teaching practice. The fact that the practice mentors are good role models and reflect their knowledge and professional competencies allows pre-service teachers to get more efficiency from this process. Informing the pre-service teachers about the teaching methods and techniques, providing them with the opportunity to explain the lesson with observation, and evaluating their performance in the classroom are among the duties and responsibilities of the mentor. During the teaching practice course, the pre-service teacher needs to experience the process of preparing, explaining, and evaluating an effective lesson plan, to get to know the students closely, and to establish healthy communication with them (Çetintaş \& Genç, 2005). At this point, the professional competencies of the practice mentor are also quite important. Similarly, Kiraz (2001) states in his research that the cognitive and affective competence of the mentor while teaching the practice course is an important factor in the success of pre-service teachers. Senemoğlu (1991) states that the subject areas in the primary education curriculum are also learned during the teaching practice most effectively. In this sense, since it is the familiarity of the teachers who guide the pre-service teachers with the distance education process is new, it is vital to provide the necessary support to the teachers. This will have a significant impact on both their professional development and the improvement of the pre-service teachers they guide.

\section{Opinions of pre-service teachers towards students in the distance education process}

The opinions of the prospective teachers towards students during the internship process carried out with distance education are presented in the "Figure 4" below.

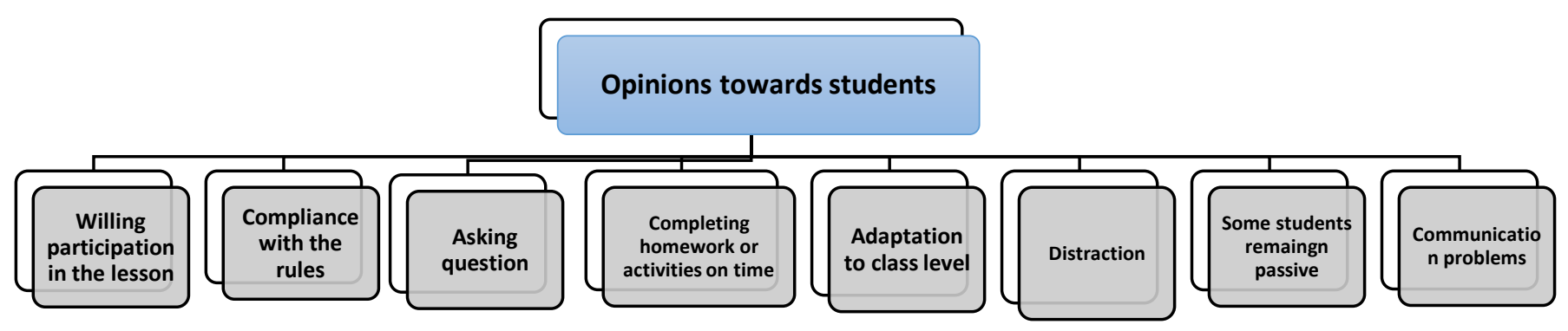

Figure 4. Opinions of pre-service teachers towards students in the distance education process

When Figure 4, which presents the opinions of the pre-service teachers towards the students were examined, it was stated that they participated in the lesson willingly within the scope of positive opinions, they comply with the classroom rules regarding distance teaching, they were active in terms of asking questions and questioning, they completed the assigned homework and activities on time, and they were suitable for teaching with distance education in terms of class levels. It was determined that pre-service 
teachers handled the most opinions in the category of "willing participation in the lesson". Some of the opinions of pre-service teachers suitable for these themes are as follows.

K1. In other words, I observed a class in which students were generally enthusiastic, participating, and ready to listen. To mention at this point, it is possible to say that the students of the class we have observed are also willing participating in the classroom environment because they also perform the actions I have listed.

K8. Although there is distance education to answer the questions asked, students who raise their hands' answer when they have the right to speak and listen to all their classmates and do not neglect to raise their hands when asked again. Students who do not disturb the lesson in the classroom listen to their teachers carefully and do not cause any problems in distance education. When students do an activity, they pay attention to textbooks, paint, notebooks, all the tools are ready. They comply with all class rules, even online.

K7. The students we observed are responsible, do their homework on time, are willing to participate in the lesson, follow the rules, and have the ability to ask question and questioning them.

K4. I truly liked the student profile. This may be due to the fact that they are in the $3^{\text {rd }}$ grade. Because let's assume that they are $1^{\text {st }}$ grade, I think they could not understand every subject directly. Therefore, it is very important what the class levels are in distance education. This is more difficult for $1^{\text {st }}$ and $2^{\text {nd }}$ grade students who do not even know how to read and write, and who do not fully understand what they read.

K3. In my opinion, the class level of the students in this process is extremely important. Being a $3^{\text {rd }}$ garde student is an advantage. Compared to the younger ones, they have experienced more face-to-face education and have come to a level where they can adapt more quickly to distance education during the pandemic period.

When the views of the pre-service teachers towards the students were examined, it was stated that the students experienced distraction, some students remained passive in the lesson and there were communication problems between the student-teacher and student-student within the scope of negative opinions. It was determined that pre-service teachers handled the most opinions in the category of "communication problems". Some of the opinions of pre-service teachers suitable for these themes are as follows.

K2. The attention level of the students is very low. There are unexpected situations such as a student talking during the lesson or knocking on the door in their home. As a result, the attention of the students is easily distracted. As such, it becomes difficult for students to focus on the lesson again.

K4. While some students want to be very active, others prefer to remain silent. This prevents every student from getting the same output from the course. Introverted students, who normally remain silent, are more likely to get distracted. Other active students get ahead of these students. Although it is a situation that we do not want at any time, it becomes difficult for every student to achieve success, realize the outputs, and form meaningful and permanent learning.

K5. Students want to show their teacher everything they do as in school, but it causes complexity as they try to do this in a digital environment. When the teacher asks a student a question, the other students answer without waiting for the question to be answered, sometimes interrupting their friends. $\underline{\text { Communication }}$ accidents are inevitable.

When the views of the pre-service teachers were examined, it was determined that they had problems especially concerning communication. When the studies in the literature are examined, Cakın and Akyavuz (2020) similarly argue that teachers have problems with communication in their research. Bakioğlu \& Çevik (2020) in their study with science teachers have observed that they encounter problems such as communicating with students and the low rate of participation in classes. In the research conducted by 
Karadüz, Eser, Şahin, and İlbay (2014) before the pandemic, it was determined that pre-service teachers had problems in terms of communication and classroom management in teaching practice. In this sense, it has been understood that the communication problem, which has a very important position in practice courses such as teaching practice, can arise both in face-to-face and distance education processes.

Pre-service teachers stated that some students were more passive in the lesson and observed problems in their interest. In this sense, Dede et al. (2021, p.131), as a result of their study on the participation of secondary school students in the course of the Covid-19 pandemic process, show that the control is largely up to the student, especially in participating in distance education and ensuring continuity in classes, and that self-regulation skills are more important in providing this control. We can include Web 2.0 tools in the education process by making the right planning to attract the attention of the students, increase their active participation in the lesson and provide more permanent learning. For example, Başaran and Kılınçaraslan (2021) examined the effect of the games designed following the lesson acquisition with Web 2.0 tools in the first-class level of primary school in the distance education process on the primary reading and writing skills of the students. They found that the students who learned the letters by Web 2.0 tools were more successful in recognizing the letter, spelling, and reading the texts in which the related letter was used intensively than the students who learned the letters conventionally. In their research, they suggest that teachers can design fun and attention-grabbing games in order to facilitate reaching affective goals so that all students in the classroom can participate more willingly in the distance education process.

\section{Opinions on the advantages and limitations of the distance education process and internship practices for pre-service teachers}

The opinions of the pre-service teachers about advantages and limitations of internship practices carried out with distance education are presented in the "Figure 5" below.
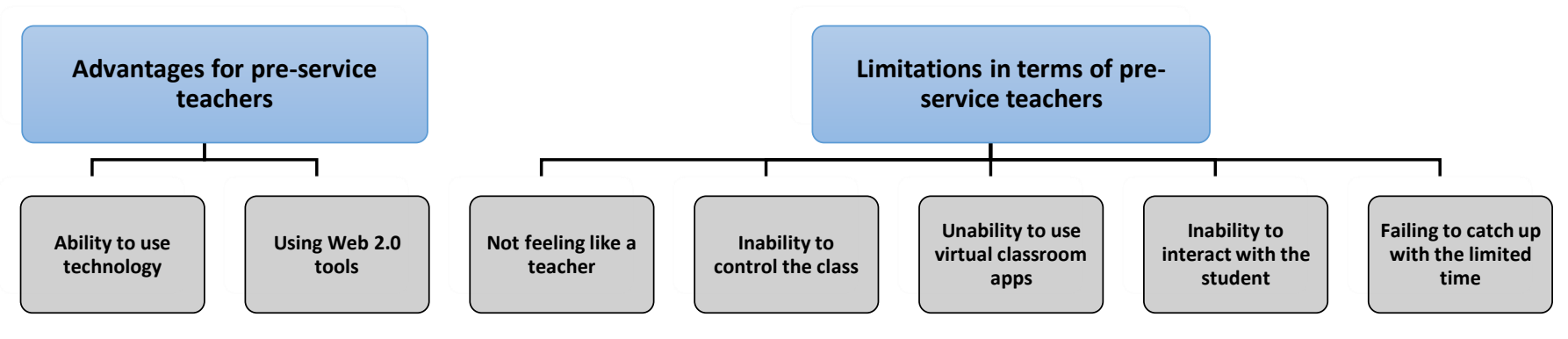

Figure 5. Opinions on the advantages and limitations of the distance education process and internship practices for pre-service teachers

When Figure 5, which presents the the opinions of the pre-service teachers about advantages and limitations of internship practices carried out with distance education, they stated that there should be a face-to-face internship practice instead of the internship practices they performed during the distance education process and they turned this situation into an advantage in two aspects. The first of these is the development the usage of technology skills in this process, and the second is that they started to use applications such as Web 2.0 tools more in their lessons. Some of the opinions of pre-service teachers in line with these themes are as follows:

K6. As an advantage, I have tested how I can use technology more beneficially and effectively in education. I have gained the knowledge and skills of many Web 2.0 tools that I can use throughout my teaching life.

K5. My interest in technology increased, I learned how to use the computer instead of just turning it on and off. I realized what I could do with computers and technology for students. 


\section{K2. I learned many $\underline{\text { Web } 2.0 \text { tools }}$ in this process.}

The pre-service teachers expressed the limitations of the distance education process and internship practices as not being able to feel like a teacher, not being able to control the classroom, not being able to keep up with the time, not being able to interact with the student, and feeling inadequate. Some of the opinions of pre-service teachers suitable for these themes are as follows.

K2. I couldn't feel like a teacher exactly because there was no school environment. I would like to interact more with the students. This year, I had many different things to do with my dream students, but I could not fully realize my plans in the distance education system.

K6. As a disadvantage, the energy and communication in the classroom environment that we caught at school was not caught in distance education due to not being able to interact with the students, not being able to be face to face, and some technological and technical difficulties.

K5. I had the most difficulty in classroom management. Students are not like in school in the distance education system, it becomes difficult to provide classroom management. They all want to speak, to say something, which causes confusion.

K3. While it is a technical difficulty and problem to control the students and observe the participation and attention status of the students at the same time while making a presentation from the computer, it becomes difficult to produce a solution for this.

K4. I had the most difficulty in catching up with the limited time and teaching how to use practices such as virtual classroom applications (Eba, Edmodo).

When the views of the pre-service teachers are examined, the finding that they feel professionally inadequate, such as not being able to feel like a teacher due to the limitations of the distance education process and internship practices, is similar to the research conducted by Güven \& Uçar (2021). Güven and Uçar (2021) stated that teacher candidates do not find distance education sufficient due to internet problems and that especially teaching practice course with distance education will create problems for them to gain experience. Similarly, Aydin (2021) examined the views of pre-service science teachers within the scope of the teaching practice course during the pandemic period. As a result of the research, it has been found that pre-service teachers may have professional problems, especially in subjects such as classroom management and poor communication.

Within the scope of the Teaching Practice course, it has been observed that the internship teachers conduct their courses through Zoom and EBA platforms. At this point, pre-service teachers who could use Web 2.0 tools comfortably during the Teaching Practice course stated that they had some difficulty in using platforms such as Zoom and EBA. Şimşek et al. (2021) determined that university students studying online have a moderate level of satisfaction with online education, and Zoom and Canvas were the most preferred in this process.

\section{Opinions of pre-service teachers regarding remote teaching of practice courses}

The opinions of the pre-service teachers regarding the distance education of the practical courses are presented in "Figure 6" below. 


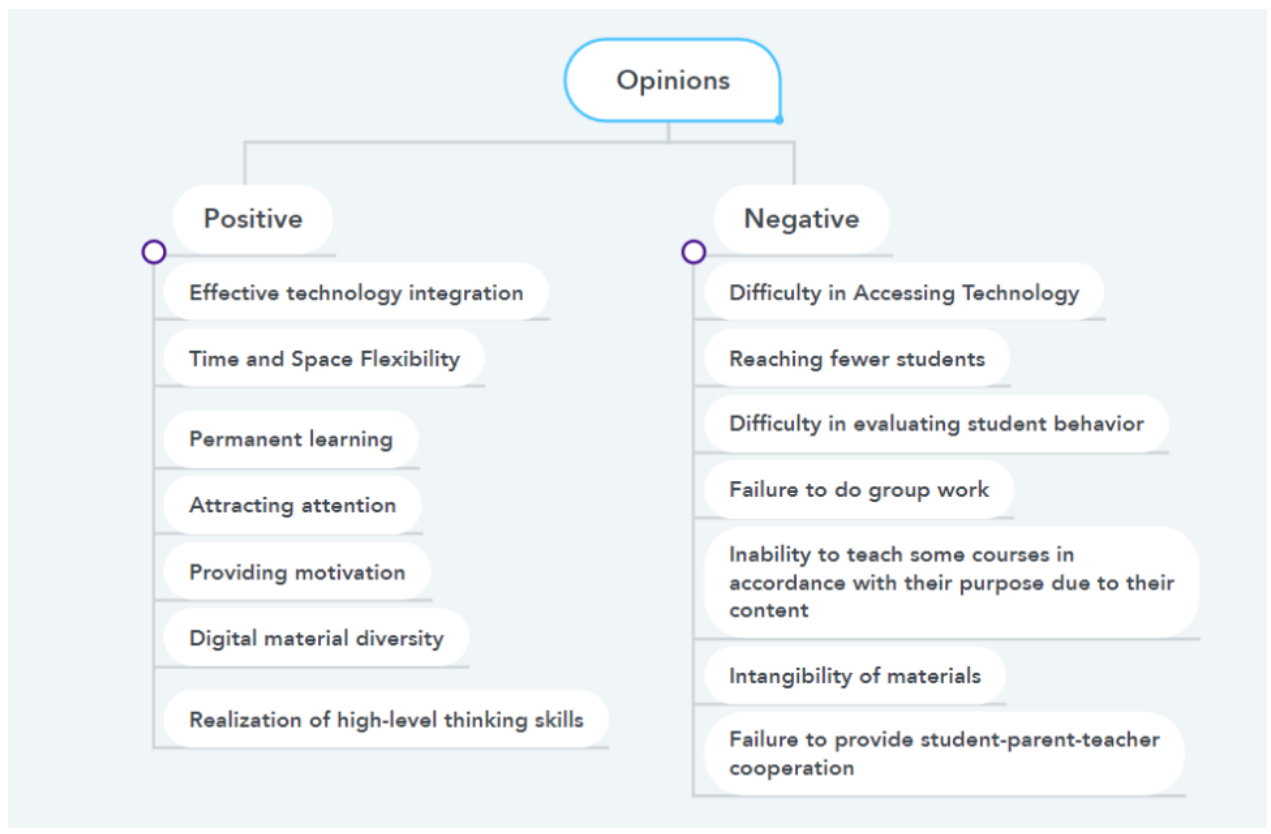

Figure 6. Opinions of pre-service teachers regarding remote teaching of practice courses

As seen in Figures 6 pre-service teachers expressed opinions in two categories (positive and negative) regarding the remote teaching of practice courses. In particular, all pre-service teachers mentioned the importance of effective technology integration. In this context, they stated that as a result of the effective integration of technology into the lessons, students will be able to learn permanently, drawing their attention will be more possible, motivation will be provided, digital material diversity will increase and students can develop high-level thinking skills. The other category they expressed for remote teaching of practice courses was determined by the theme of the flexibility of time and space. Some of the opinions of pre-service teachers suitable for these themes are as follows.

K2. The course process with distance education is a platform where learning will be very permanent if technology is used effectively.

K3. Permanent learning is provided by integrating technology into the lesson. High-level thinking skills contribute to the development of attention. The teacher's use of Web 2.0 tools in distance education brings vitality to the lesson, the student behind the computer will be more active instead of bored. Addressing more senses will also increase the permanence of learning.

K4. When technology is transferred into the lesson, the student will be more active and participation in the lesson will be much higher. Not only by reading, hearing, or seeing the information that students need to learn but also by providing studies on that subject will make a great contribution to the student. Otherwise, if the subject is explained only verbally, the permanence of the learning will be very low.

K7. Distance education is an ideal place to reach many students. If the subject is many people, lectures here are easy to save time.

K8. Both students and teachers were taking actions such as coming to school in order to unite in the classroom environment, but it is not possible to talk about such a situation in distance education, so we can say that time is saved.

K6. There is an advantage in distance education such as the use of different techniques, there is flexible time, people can follow their lessons in a suitable learning environment. 
The themes that pre-service teachers expressed negative opinions about remote teaching of practice courses are; difficulty in accessing technology, difficulty in evaluating student behavior, inability to do group work, inability to teach some courses per their purpose due to the content, intangibility of materials, failure to provide student-parent-teacher cooperation, failure to provide classroom order. Some of the opinions of pre-service teachers suitable for these themes are as follows.

K1. We can say that it reaches fewer students if we consider that not all children have facilities such as computers or the internet, and it can be said that these opportunities will prevent these children from learning.

K8. It can be said that distance education does not provide equality of opportunity, as there are situations such as students' lack of technology or access to the course is a problem.

K4. I think the point where distance education affects students the most is as follows; their inability to observe their behavior. The teacher will not be able to see how the students behave with their friends during the lesson, after the lesson, or in the garden. They will not be able to gain the habits and skills that the teacher should give them.

K2. Physical education, music, and visual arts lessons, which contribute to the mental and physical development of students, are limited to the teacher's playing music on YouTube or make them paint. In particular, the physical education lesson cannot be carried out under its purpose. While this course enables students to socialize together, this is not possible to do this in distance education. Since the students are at home, they are much more comfortable than they are in the school environment, there is no certain order and discipline. Group work among students is not possible. Courses based on experiments and observation, such as science, are taught by direct instruction method.

K5. Since visual arts, physical education, and game and music lessons cover artistic works in the category of practice lessons, teaching them in distance education affects the students in a way that they will have lack skills or that they will have some deficiencies.

K3. I think that there are difficulties in providing student-parent-teacher cooperation. Calling the families of students who could not be reached via the internet and trying to include them in the program created an advantage for students not to fall behind in the classes and school program.

K6. It is not a system that allows the use of materials and physical interaction (eye contact, hand, arm contact) with our teacher in the distance education process as much as formal education. It is not a system that appeals to visual memory since students cannot see the materials concretely.

The theme of the flexibility of time and space, especially for the remote teaching of practice courses such as teaching practice, which emerged during the interviews with the pre-service teachers, is similar to the research results of Çilek, Uçan, and Ermiş (2021). As a result of the research conducted by Çilek, Uçan, and Ermiş (2021) with primary school teachers, it was determined that the most frequently expressed positive opinions by teachers were that distance education provides flexibility and comfort and provides students with plenty of resources, quick access to resources and more repetition.

In this study, themes emerged regarding both positive and negative views of pre-service teachers towards teaching the lesson remotely. Şeren, Tut \& Kesten (2020) also examined the views of basic education instructors on distance education during the coronavirus pandemic period. In the study, the views of the instructors in terms of the teaching-learning process, communication-interaction, and assessmentevaluation in distance education were discussed in terms of both disadvantages and advantages. It was suggested that their views on disadvantages were more than their views on advantages. At this point, they used various methods to solve problems and make constructive suggestions for making the process more efficient. 
Among the negative opinions of pre-service teachers are the themes of "difficulty in accessing technology" and "reaching fewer students". Similarly, Kavuk and Demirtaş (2021), in their research, found that students could not reach enough technological tools and the internet, they had some problems with EBA, and because of these, the rate of participation in the course decreased. Liyanagunawardena \& Williams (2021), in their study investigating the reflections of emergency distance education and home education during the Covid-19 pandemic in Sri Lanka, argued that both students and parents were more satisfied with the emergency distance education process, especially in states with good computer equipment. Similarly, in the research conducted by Karakuş, Ucuzsatar, Karacaoğlu, Esendemir and Bayraktar (2020), teacher candidates stated that they could not get efficiency due to technical problems and lack of communication during the pandemic process.

\section{Suggestions for solutions to the problems experienced in the distance education experiences of pre-service teachers}

The suggestions for solutions to the problems experienced in the distance education experiences of preservice teachers are presented in the "Figure 7" below.

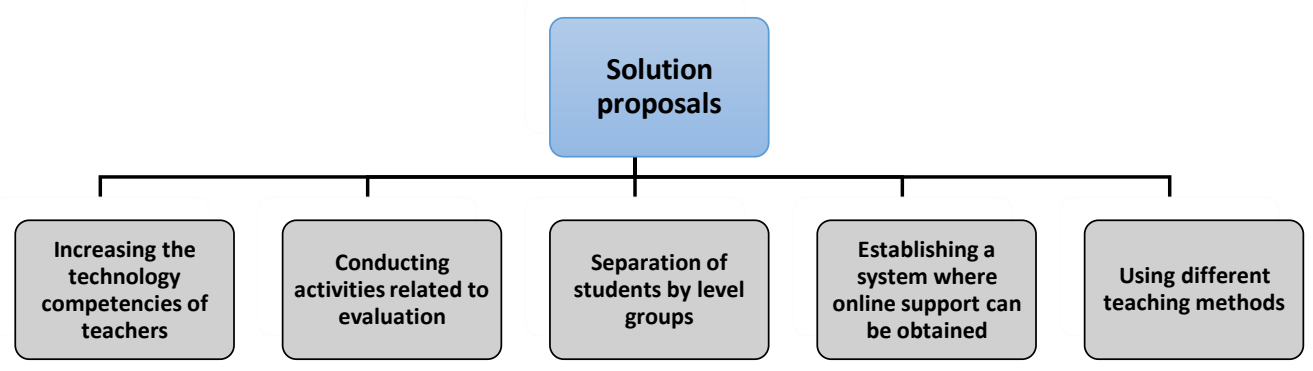

Figure 7. Suggestions for solutions to the problems experienced in the distance education experiences of pre-service teachers

As seen in Figure 7, pre-service teachers stated their solution suggestions for the problems they encountered in their distance education experiences under 5 themes. These themes are; the technology competence of teachers should be increased, activities related to assessment should be carried out in the classroom, students should be separated according to their level groups, a system should be created where teachers can receive online support for technical problems or online platforms, and distance education courses should be carried out by using different teaching methods. Some of the opinions of pre-service teachers suitable for these themes are as follows.

K2. Teachers need to be more involved in technology and should make their preparations in advance.

K3. The only suggestion I will make, based on my own internship experience during the distance education process, is for our teachers to teach the questions in the lectures by turning them into play on digital platforms. In this way, I think that students learn more willingly and faster. Thanks to these games, students can both play and learn individually after the lesson is over. But for this, it is necessary to improve the technology competencies of teachers.

K5. Making more technology-based practices, presenting more examples, microteaching practices, seperation of groups according to levels, less number of students, creation of a system where online support can be obtained, applying a new program for advanced practices (laboratory, painting, music, 
physical education classes, etc.), sending reminder messages and doing activities related to the evaluation are among my suggestions.

\section{K7. I think that direct instruction should be avoided and emphasis should be placed on various teaching methods and techniques.}

When the studies on distance education in the literature are examined, it is noteworthy that the problems identified and the suggestions for the solution of the problems are similar. For example, Sharma et al. (2021), as a result of their research they conducted with nursing faculty students in Nepal on emergency distance education applications during the pandemic period; it has been determined that almost all of the participants preferred live lessons to recorded lessons, and the majority of students and faculty members are not interested in online lessons. In the research; although communication and cooperation have increased, it has been determined that the overall effectiveness of distance education is low and therefore it is stated that the right strategies are needed to increase effectiveness. Agnoletto and Queiroz (2020) emphasize that digitalization is not as easy as it seems and that it is necessary to cope with the feelings of anxiety arising from social isolation, especially due to the pandemic. They state that all educational difficulties (material diversity, motivating activities, planning steps, etc.) that already exist in classrooms should be handled more carefully in the distance education process, due to the inherent uncertainties of the process. In the research of Çilek, Uçan \& Ermiş (2021), it was stated that there are problems in the distance education process such as internet and computer inadequacy, loss of motivation, technical problems, the inadequacy of technology usage, parent interventions, and lack of socialization, and there have been suggestions such as providing equal opportunities for teachers, technological training for parents, the EBA platform to be designed with contents based on primary schools and strengthening the internet infrastructure of schools. Hebebci, Bertiz, and Alan (2020) investigated the opinions of teachers and students on distance education practices in the COVID-19 pandemic. In the interviews, they determined that there are problems such as lack of infrastructure and equipment and stated that improvement activities can be planned, especially with in-service trainings, in order to solve these problems.

\section{Conclusion and Suggestions}

The Covid-19 pandemic has suddenly become a part of our lives and has caused serious changes and transformations in almost all sectors in the world. In particular, the reflections of the suspension of face-toface education and the transition to emergency distance education will be more clearly understood in the following years. In the distance education process, within the scope of the "Teaching Practice" course, 2 hours a week theoretically with the instructor and the remaining 6 hours were carried out online under the guidance of the practice teacher in schools affiliated with the MoNE. The course is practiced within the time allotted for the course under the provisions of the curriculum and legislation applied at the field and education level of which the pre-service teacher will teach. It consists of arranging lesson plans, preparing for the lessons, and creating instructional activities according to the level of the class in which the lesson is followed. However, due to the pandemic, it has become necessary to conduct the theoretical and practical part in the form of distance education. In this context, within the scope of the teaching practice course, the views of pre-service teachers about their distance education experiences are included in the study. When the results of the study are examined, when the opinions of the primary school pre-service teachers especially towards the practice mentors are examined, it is seen that the teachers give timely and appropriate feedback to the students during the distance education process, they can evaluate the success of the students, they give the students the appropriate time while answering the questions, and they inform the students about the outputs before the lesson starts. It has been determined that they do not include technology-based practices (Web 2.0 practices), they teach by using the direct instruction method, and they do not prepare a lesson plan or activity plan. Pre-service teachers also stated that teachers use platforms such as EBA and Edmodo more effectively, but they never add Web 2.0 practices to the lesson. In this context, they have revealed that while they feel more competent in Web 2.0 practices, they cannot participate actively in 
platforms such as EBA and Edmodo and that teachers use these platforms more competently. When the opinions of the pre-service teachers towards the students are examined, it is stated that they attend the lesson willingly within the scope of positive opinions, they comply with the classroom rules regarding distance teaching, they are active in terms of asking questions and questioning, they complete the given assignments and activities on time, and they are suitable for teaching with distance education in terms of class levels; within the scope of negative opinions, it was stated that students experienced distraction, some students remained passive in the lesson, and communication problems were experienced between student-teacher and student-student. Pre-service teachers stated that their technology usage skills have improved thanks to the internship practices they have carried out during the distance education process, and they have started to use applications such as Web 2.0 tools more in their lessons. In this context, their effective use of Web 2.0 tools can be attributed to the technology integration-based education process that the practice instructor gave throughout the teaching practice course. The pre-service teachers stated the limitations of the distance education process and internship practices as not being able to feel like a teacher, not being able to manage the classroom, not being able to keep up with the limited time, not being able to interact with the students, and feeling inadequate. Pre-service teachers stated that remote teaching of practical courses can only be achieved by providing effective technology integration. In this context, they expressed the opinion that primary school students will provide permanent learning, they can achieve more attention, motivation will be provided, digital material diversity will increase and students can develop high-level thinking skills. Preservice teachers reported more negative opinions about remote teaching of practice courses. These themes are; difficulty in accessing technology, difficulty in evaluating student behavior, inability to do group work, inability to teach some courses per their purpose due to the content, intangibility of materials, failure to provide student-parent-teacher cooperation, failure to provide classroom order.

In this study, it is known that the effects of completing the "Teaching Practice" course in distance education will be understood in the following years, especially for the prospective teachers who will be the primary school teachers of the future. When the results of this study are taken into consideration, it may cause a lack of experience, especially if courses such as teaching practice, which are practice-based, are carried out in distance education. It is very important to compensate for this forced situation. Especially during the pandemic period, remedial training can be given to teachers who graduated and appointed; and different activities, in-service training, and courses can be organized to adapt to the school and students. In cases where it is necessary to conduct practical courses such as teaching practice in distance education, it should be shared with all participants at the beginning of the term, especially where the attendance requirement is important. It is also important for prospective teachers to be active in weekly theoretical lecture meetings to ensure their motivation. The problems they have experienced during the internship should be shared with the lecturer and solutions should be discussed. They should have regular meetings with the class teacher and obtain information about the primary school students that they observe and need to teach. Primary school teachers are required to follow the weekly lessons regularly and arrange the lesson plan they will teach with methods-techniques suitable for distance education.

They can benefit from different Web 2.0 technologies to ensure the participation of students in the courses which will be taught in distance education. Instead of using only PowerPoint presentations in lessons, they can be guided to design activities with different concepts such as attracting attention, playing games, and evaluating. In this sense, it is very important that the academicians responsible for the course in the university and the primary school teacher in the MoNE school working in coordination.

Another important point is that; some pre-service teachers may have problems with internet access at the time they will teach during the internship. For this reason, it is necessary to talk to the teachers in charge of the course in advance about finding a solution and how they can benefit from the opportunities. Especially in the 2020-2021 academic year, the libraries of universities affiliated to CHE have been back in service for students who have internet problems in their villages, districts, and provinces, for the problem of accessing the internet in the courses of their undergraduate program. Students who have internet problems 
at home can continue to benefit from the internet of the universities in their province. In addition, all students can be facilitated if authorities try to eliminate the necessary infrastructure deficiencies in internet connection as soon as possible.

\section{References}

Agnoletto, R., \& Queiroz, V. (2020). COVID-19 and the challenges in Education. The Centro de Estudos Sociedade e Tecnologia (CEST), 5(2).

Allen, M., Bourhis, J., Burrell, N., \& Mabry, E. (2002). Comparing student satisfaction with distance education to traditional classrooms in higher education: A meta-analysis. The American Journal of Distance Education, 16(2), 83-97.

Aydın, S. (2021). Covıd-19 Pandemisi sürecinde fen bilimleri öğretmen adaylarının öğretmenlik uygulaması dersi ile ilgili görüşleri, International Journal of Eurasia Social Sciences (IJOESS), 12(45), 677-693.

Bakioğlu, B., Çevik, M. (2020). COVID-19 pandemisi sürecinde fen bilimleri öğretmenlerinin uzaktan eğitime ilişkin görüşleri. Turkish Studies, 15(4), 109-129.

Baran, E. \& AlZoubi, D. (2020). Human-Centered Design as a Frame for Transition to Remote Teaching during the COVID-19 Pandemic. Journal of Technology and Teacher Education, 28(2), 365-372. Waynesville, NC USA: Society for Information Technology \& Teacher Education. Retrieved August 30, 2021 from https://www.learntechlib.org/primary/p/216077/.

Başaran, M., \& Kilınçarslan, R. (2021). The efficiency of games designed with web 2.0 tools in primary reading and writing teaching with distance education. Turkish Journal of Education, 6 (1), 186-199.

Bilgiç, H. G., \& Tüzün, H. (2015). The problems experienced web-based distance education programs in higher education institutes. Journal of Open Education Applications and Research, 1(3), 26-50.

Bozkurt, A., \& Sharma, R. C. (2020). Emergency remote teaching in a time of global crisis due to CoronaVirus pandemic. Asian Journal of Distance Education, 15(1), i-vi.

Can, E. (2020). Coronavirüs (Covid-19) pandemisi ve pedagojik yansımaları: Türkiye'de uzaktan eğitim uygulamaları. Açıköğretim Uygulamaları ve Araştırmaları Dergisi, 6(2), 11-53.

Council of Higher Education (CHE) (2020). Press release, Retrieved from https://www.yok.gov.tr/Sayfalar/Haberler/2020/

Çakın, M., \& Külekçi Akyavuz, E. (2020). Covid-19 süreci ve eğitime yansıması: Öğretmen görüşlerinin incelenmesi. International Journal of Social Sciences and Education Research, 6(2), 165-186.

Çetintaş, B., \& Ayten, G. E. N. Ç. (2005). Almanca öğretmen adaylarının öğretmenlik uygulaması derslerine ilişkin görüş ve deneyimleri. Hacettepe Üniversitesi Ĕ̈itim Fakültesi Dergisi, 29(29), 75-84.

Çilek, A., Uçan, A., \& Ermiş, M. (2021). Pandemi sürecinde sınıf öğretmenlerinin uzaktan eğitime ilişkin görüşleri. Turan Stratejik Araştırmalar Merkezi, 13(49), 308-323.

Durak, G., Çankaya, S., \& İzmirli, S. (2020). Examining the Turkish universities' distance education systems during the COVID-19 pandemic. Necatibey Faculty of Education Electronic Journal of Science and Mathematics Education, 14(1), 787-809.

Güven, S., \& Uçar, M. (2021). Öğretmen adaylarının uzaktan eğitim ve öğretmenlik uygulaması dersine ilişkin görüşleri. Journal of Awareness, 6(3), 165-183. 
Hebebci, M. T., Bertiz, Y., \& Alan, S. (2020). Investigation of views of students and teachers on distance education practices during the Coronavirus (COVID-19) Pandemic. International Journal of Technology in Education and Science (IJTES), 4(4), 267-282.

Hojeij, Z., \& Baroudi, S. (2021). Engaging pre-service teachers in virtual field experience during cov1d-19: designing a framework to inform the practice. International Journal of Distance Education Technologies (IJDET), 19(3), 14-32.

Iyer, P., Aziz, K., \& Ojcius, D. M. (2020). Impact of COVID-19 on dental education in the United States. Journal of Dental Education, 84(6), 718-722.

Kahraman, M. E. (2020). COVID-19 salgınının uygulamalı derslere etkisi ve bu derslerin uzaktan eğitimle yürütülmesi: temel tasarım dersi örneği. Medeniyet Sanat Dergisi, 6 (1), 44-56. DOI: 10.46641/medeniyetsanat.741737

Karadüz, A., Eser, Y., Şahin, C. \& İlbay, A. (2014). The effectiveness of teaching practice module in opinions of final-year student teachers. Mustafa Kemal Üniversitesi Sosyal Bilimler Enstitüsü Dergisi, $\quad 6 \quad$ (11), 440-453. $\quad$ Retrieved from https://dergipark.org.tr/en/pub/mkusbed/issue/19558/208501.

Karakuş, N., Ucuzsatar, N., Karacaoğlu, M. Ö., Esendemir, N. \& Bayraktar, D. (2020). Türkçe öğretmeni adaylarının uzaktan eğitime yönelik görüssleri. RumeliDE Dil ve Edebiyat Araştırmaları Dergisi, (19), 220-241.

Kavuk, E.\& Demirtaş, H. (2021). COVID-19 pandemisi sürecinde öğretmenlerin uzaktan eğitimde yaşadığ1 zorluklar. E-International Journal of Pedandragogy, 1(1), 55-73.

Kiraz, E. (2001). Aday öğretmen-rehber öğretmen etkileşimi: Mesleki gelişimde diğer boyut. Ĕ̆itim araştırmaları, 5, 85-92.

Liyanagunawardena, T., \& Williams, S. A. (2021). Emergency remote education: experience from Sri Lanka during covid-19. Asian Journal of Distance Education, 16(1), 207-229. Retrieved from http://www.asianjde.com/ojs/index.php/AsianJDE/article/view/554.

Merriam, S. B. (2018). Nitel araştırma: Desen ve uygulama için bir rehber. S. Turan (Çev. Edt.). Nobel Yayınevi.

Miles, M. B. \& Huberman A. M. (1994). An expanded sourcebook qualitative data analysis. California: Sage Publications.

Ministry of Health (2020). Covid-19 (Sars-CoV-2 Infection) Guide. Erişim: https://covid19bilgi.saglik.gov.tr/depo/rehberler/COVID-19_Rehberi.pdf (Erişim Tarihi: 16.07.2020)

Mohammad Nasri, N., Husnin, H., Mahmud, S. N. D., \& Halim, L. (2020). Mitigating the COVID-19 pandemic: A snapshot from Malaysia into the coping strategies for pre-service teachers' education. Journal of Education for Teaching, 46(4), 546-553.

Nel, C., \& Marais, E. (2020). Preservice teachers use of Whatsapp to explain subject content to school children during the COVID-19 Pandemic. International Journal of Work-Integrated Learning, 21(5), 629-641.

Patton, M.Q. (2002). Qualitative research \& evaluation methods (3rd ed.). Thousand Oaks, CA: Sage.

Russel, T. L. (1999). The No significant difference phenomenon as reported in 355 research reports, summaries and papers. USA: North Carolina State University. 
Senemoğlu, N. (1991). A study on initial primary teacher training in England with implications for the system in Turkey. Hacettepe Üniversitesi Ĕ̈itim Fakültesi Dergisi, 9(9), 367-376.

Sharma, M., Onta, M., Shrestha, S., Sharma, M. R., \& Bhattarai, T. (2021). The pedagogical shift during Covid-19 pandemic: emergency remote learning practices in nursing and its effectiveness. Asian Journal of Distance Education, 16(1), 98-110. Retrieved from http://www.asianjde.com/ojs/index.php/AsianJDE/article/view/537.

Şimşek, I., Küçük, S., Köse Biber, S., \& Can, T. (2021). Online learning satisfaction in higher education amidst the Covid-19 pandemic. Asian Journal of Distance Education, 16(1), 247-261. Retrieved from http://www.asianjde.com/ojs/index.php/AsianJDE/article/view/561.

Şeren, N., Tut, E., \& Kesten, A. (2020). Korona virüs sürecinde uzaktan eğitim: Temel eğitim bölümü öğretim elemanlarının görüşleri. Turkish Studies, 15(6), 4507-4524.

Türküresin, H. E. (2020). Examining the distance education applications carried out during the Covid-19 pandemic period in the context of the views of teacher candidates. Milli Eğitim Dergisi, 49(1), 597618.

UNESCO (2020). COVID-19 education from https://en.unesco.org/covid19/educationresponse/globalcoalition.

Valdez, P. N., Ugalingan, G., \& Edjan, D. (2021). Exploring conditions of possibility for the teaching internship in the Philippines during the COVID-19 pandemic. Journal of Public Health, fdab225, Retrieved from https://doi.org/10.1093/pubmed/fdab225.

Yıldırım, A. \& Şimşek, H. (2014). Sosyal bilimlerde nitel araştırma yöntemleri. Ankara: Seçkin Yayıncılık

Yıldırım, S., Yıldırım, G., Çelik, E., \& Karaman, S. (2014). Distance education students' views on distance education: a scale development study. Ĕgitim ve Ögretim Araştırmaları Dergisi, 3(3), 365-370. 